IRSH 49 (2004), pp. 475-515 DOI: I0.1017/S0020859004001762

(C) 2004 Internationaal Instituut voor Sociale Geschiedenis

\title{
REVIEW SYMPOSIUM
}

\section{Cultures in Contact}

In 2002, Dirk Hoerder published his magnum opus, Cultures in Contact: World Migrations in the Second Millennium (Durham, NC, 2002). In this book, Hoerder describes and analyses, with an unusual breadth of scope, the origins, causes, and extent of human migration around the globe from the eleventh century onward to the present day, paying particular attention to the impact migrations have had in the receiving countries and the cultural interactions they have triggered. At the 28th Annual Meeting of the American Social Science History Association, organized in November 2003 in Baltimore, Dirk Hoerder's book was the winner of the Allan Sharlin Memorial Award for the best book in social science history.

In this review symposium, seven migration scholars from differing national and cultural backgrounds give their comments on Hoerder's book, with a concluding response by Dirk Hoerder.

The Editors 


\title{
Introduction
}

\author{
Donna GABACIA
}

A book such as Cultures in Contact does not emerge from nowhere. It seems worthwhile to pause and to consider its prehistory before praising its strengths, listing its weaknesses, or discussing its legacy for future scholarship. How does a book as ambitious and wide-ranging as this one come to be written? How do scholars attain the global perspectives and the respect for individual idiosyncrasy that one finds throughout Cultures in Contact? An answer to those questions must be, in part, biographical.

Dirk Hoerder was not trained as a world historian. No-one of his generation was charged by a mentor with the task of writing global history. (Few enough are being so charged or trained even today.) Hoerder's I97 I dissertation on crowds in the American Revolution instead bears all the characteristics of "history from below", as it was practiced in the United States during the I960s and I970s. Its focus on the poor and uneducated, and its concern with the agency and decision-making of ordinary workers forced to make choices, and thus history, under conditions they could not control, suggest a thorough grounding in historical methods associated with the new left and with the new social history as it developed in the United States. Given all that Hoerder later wrote about the cultural complexities of migrants' lives, it would nevertheless be a mistake to portray his attraction to American "history from below" as a case of an academic labor migrant's intellectual assimilation. On the contrary, even as a visiting graduate student at Minnesota and at Harvard, Hoerder wrote American history as a European, and as one as much influenced by the politics and the debates of Berlin as of Boston. ${ }^{\mathrm{I}}$ Like many of his German scholarly cohort, he may have been attracted to the US but mainly to its history of insurgency, rebellion, and scholarly innovation.

Perhaps because he also began as a specialist on an era when continentand ocean-spanning European empires were about to generate a new age of nationalism, Hoerder also became fascinated with scales of historical

I. Dirk Hoerder, "People and Mobs, Crowd Action in Massachusetts During the American Revolution, I765-1780", (Ph.D. dissertation, Berlin, I971). The dissertation was published in the US as Crowd Action in Revolutionary Massachusetts, $1765-1780$ (New York, 1977). See also Dirk Hoerder, Society and Government 1760-1780: The Power Structure in Massachusetts Townships (Berlin, 1972). 
analysis above and below that of the individual national state. Throughout the I970s, he apparently saw first in labor history, and later in what (at the time) was called "immigration history", ways to link history from below to international analysis through the study of the intimate details of mobile workers. His intensive work in bibliography during these years clearly reveals his engagement with the themes - of social protest, labor, and the relationship of society and culture - that persisted through all his subsequent writings. ${ }^{2}$

By the time I met him in 1980, Hoerder's work suggested what could happen when a scholar contemplates American Studies not only "from below" but "from the outside". His second book, (it focused on German views of the American labor movement), might be considered an early example of an Atlantic history in which European intellectuals and state agents play a central role. ${ }^{3}$ Although he never completely lost interest in the analysis of German-American transatlantic relations, ${ }^{4}$ most of Hoerder's work in the I980s and early I990s broadened the perspective of an-already accomplished European specialist on the US into that of a cosmopolitan Atlanticist who frequently traveled, researched, and taught on both sides of the ocean.

In the I980s, a series of scholarly collaborations on the human movements Hoerder termed the "proletarian mass migrations" made his Labor Migration Project in Bremen a center for the study of the modern Atlantic. (This was a development that, I am sorry to report, went practically unnoticed by colonialists of the British Atlantic who were then also busy creating Atlantic history as a field of study for the centuries between I 500 and I 800 .) While Hoerder's initial collaborations brought together US and European historians of labor and immigration, 5 much of the later work of the Labor Migration Project facilitated contacts between

2. Dirk Hoerder (ed.), Violence in the United States, Riots, Strikes, Protest and Suppression: A Working Bibliography for Teachers and Students (Berlin, 1973); idem (ed.), Studies on the Interaction of Society and Culture in American Past and Present: A Bibliography of Dissertations, 1938-1973 (Berlin, 1975); idem (ed.), American Labor History: Research, Teaching and Bibliographic Aids (Berlin, 1976); idem (ed.), Protest, Direct Action, Repression: Dissent in American Society from Colonial Times to the Present: A Bibliography (Munich, 1977).

3. Dirk Hoerder (ed.), Plutokraten und Sozialisten: Berichte deutscher Diplomaten und Agenten über die amerikanische Arbeiterbewegung I878-I9I7 (Munich [etc.], I98I).

4. Dirk Hoerder and Thomas Weber (eds), Glimpses of the German-American Radical Press: Die Jubiläumsnummern der "New Yorker Volkszeitung” I 888, 1903, 1928 (Bremen, I985); Dirk Hoerder and Jörg Nagler, People in Transit: German Migrations in Comparative Perspective, I 820-1930 (Washington DC [etc.], I 995); Josef N. Jodlbauer, Dreizehn Jahre in Amerika, I $910-$ 1923: die Autobiographie eines österreichischen Sozialisten, Dirk Hoerder (ed.) (Vienna, I996). 5. Dirk Hoerder (ed.), American Labor and Immigration History, I877-I920s: Recent European Research (Urbana, IL, 1983); idem (ed.), "Struggle A Hard Battle": Essays on Working-Class Immigrants (DeKalb, IL, I986); idem (ed.), Labor Migration in the Atlantic Economies: The European and North American Working Classes during the Period of Industrialization (Westport, CT, 1985). 
historians in eastern and central European communist states with western European and American historians. Well before 1989, Hoerder's projects (several with funding from the Volkswagen Foundation) were able to bring Polish, Hungarian, and Yugoslav specialists to the US or to the Federal Republic for joint research trips and international conferences. ${ }^{6}$ The language skills and historiographical frames of "the East" and the historical traditions of Europe painted portraits of the US, and of its working-class immigrants, that English-speaking North Americans could not have produced. Noticeable in this pan-European interpretation of the US was an emphasis on the circulation, return, transatlantic networks, and contacts of migrants; today we would label these "transnational".

Significantly, Hoerder also promoted and supported initiatives by his female and feminist colleagues and, (apparently almost alone among his cohort of male German historian colleagues) he struggled to learn and then to practice himself both the women-centered and gendered methodologies they advocated.7 Hoerder's Bremen-based projects became models for subsequent collaborative research projects, including my own "Italian Workers of the World" in the I990s. With hindsight, it now also seems indisputable that the Labor Migration Project broadened Hoerder's intellectual interests beyond the US and northern Europe. For, having begun as a practitioner of history from below, Hoerder in the I990s seemed pushed to follow laboring men and women outward - much as Latin Americanist, Sam Baily, had urged scholars of migration to do from their many villages in Europe and elsewhere ${ }^{8}$ into Canada, the Mediterranean, and western Asia, and the Pacific.

As the Bremen Labor Migration Project concluded in the early i990s, Hoerder returned to the pleasures of individual research but - unwilling to abandon the broad scope adopted in his years of collaboration -began his research on migration worldwide and over the long-term. In the process, he switched his scholarly focus from the US to Canada - producing an innovative interpretation of Canada as a nation of immigrants just two

6. Dirk Hoerder, Why Did You Come?: The Proletarian Mass Migration: Research Report, 1980-1985 (Bremen, I986); Dirk Hoerder and Christiane Harzig (eds), The Immigrant Labor Press in North America, I840s-1970s: An Annotated Bibliography (New York, 1987); Dirk Hoerder and Diethelm Knauf (eds), Aufbruch in die Fremde [Fame, Fortune, and Sweet Liberty: The Great European Emigration] (Bremen, 1992); Dirk Hoerder, People on the Move: Migration, Acculturation, and Ethnic Interaction in Europe and North America (Providence, RI, I993); Dirk Hoerder and Horst Rössler (eds), Distant Magnets: Expectations and Realities in the Immigrant Experience, 1840-1930 (New York, 1993); Dirk Hoerder and Inge Blank (eds), Roots of the Transplanted (Boulder, CO [etc.], I994); Dirk Hoerder and Leslie Page Moch, European Migrants: Global and Local Perspectives (Boston, MA, 1996).

7. Christiane Harzig, Peasant Maids, City Women: From the European Countryside to Urban America (Ithaca, NY, 1997).

8. Samuel Baily, "The Village-Outward Approach to Italian Migration: A Case Study of Agnonesi Migration Abroad, I885-1989”, Studi Emigrazione, 29 (1992), p. 105. 
years before publishing Cultures in Contact. ${ }^{9}$ As a Canadianist, albeit one now writing also about the world, Hoerder forged a new network of transatlantic connections. Convinced that Canada's concerns with language and ethnicity made it a more promising model for European multiculturalism than the monolingual US (with its primary concerns with race and color), Hoerder encouraged intellectual exchanges between specialists on Canada's policies and theories of multiculturalism and Europeans struggling to come to terms with the cultural meaning, consequences, and politics of cultural diversity within the European Union. ${ }^{10}$ In many respects, the long historical sweep of Cultures in Contact and its focus on cultural contacts, conflicts, and exchanges can be seen as Hoerder's effort to ground our understanding of the cultural battles of the present - whether in Europe, the Americas, Africa, or Asia in the past.

What does that history suggest? I suspect that no reader of Cultures in Contact can end her reading of the book without having grasped the absolute normalcy of migration, and thus the absolute normalcy of cultural change, too, in the long history of human life on earth. Hoerder's book both humanizes the study of migration and emphasizes its close ties to human sociability. In Cultures in Contact, Hoerder abandons earlier scholarly metaphors that portrayed mobile people as elements in some unthinking natural world: there are far fewer "streams", "flows", and "waves" of migrants in Cultures in Contact than, for example, in the works of social scientists. Hoerder also eschews metaphors that portray migrants botanically - as either transplanted (as in John Bodnar's work) or uprooted (as in Oscar Handlin's).

In Cultures in Contact, a reader finds himself looking at the earth from afar as a kind of human anthill, teeming with social activity; like social insects, the people of Cultures in Contact seem to swarm and hive; they are constantly and ever "on the move". Unlike social insects, however, Hoerder's migrants are not drones and workers following a fecund queen. And it is not only the useless males that sprout wings and fly away. Still the practitioner of history "from below", Hoerder is able to show us both the normalcy and the contingency - both the restraints and the choices - of mobile people and to describe in human detail the sociability of the worlds they forge as they move.

9. Dirk Hoerder, Creating Societies: Immigrant Lives in Canada (Montreal [etc.], I999). Io. Dirk Hoerder and Rainer-Olaf Schultze (eds), Socio-Cultural Problems in the Metropolis: Comparative Analyses (Hagen, 2000); Dirk Hoerder with Christiane Harzig and Adrian Shubert (eds), The Historical Practice of Diversity: Transcultural Interactions from the Early Modern Mediterranean to the Postcolonial World (New York, 2003). 


\title{
Interpreting a Millennium of Human Mobility
}

\author{
Leslie Page Moch
}

Dirk Hoerder opens this study with a concise introduction that articulates his paradigms and a discussion of the systems approach to migration and of the meso-level of migration decision-making, thus bringing the reader up to date with the latest of theories about the social organization of human mobility. Part I of the book investigates the Judeo-Christian-Islamic Mediterranean and Eurasian worlds to the I soos, focusing on the EuroMediterranean world, Ottoman society, Europe, and the beginnings of colonial contacts. Part 2 treats European colonialism to the eighteenth century, opening with a treatment of the African slave trade, then shifting to the Indian Ocean, Latin America, and fur empires to the north. The emphasis here is on worldviews, material cultures, and racial hierarchies. Part 3 surveys intercontinental migration systems to the nineteenth century, including rural colonization as well as enclosure and urbanization; it emphasizes migration systems in and to the Russian Empire, transatlantic movement, and the vast Asian contract labor systems. Part 4 belongs to the twentieth century, opening with forced labor and refugees in the northern hemisphere, then shifting to the new diasporic, labor, and refugee migrations of the past forty years. Over seventy fine maps bring this vast range of human movements to the eye.

One quickly observes that Dirk Hoerder's study is an encyclopedic one, since it offers a survey and analysis of I,000 years of migration worldwide. One reads about the travels of Song Dynasty merchants in East Africa (960-1279), refugees in Africa during the I990s, and the vast array of human mobility between the two. Yet this study also has qualities that encyclopedias do not. What encyclopedia gives the powerful a jab in the ribs at every opportunity? Hoerder does so frequently; for example, he indicates how travel writings in early modern times "transformed cultural contact into a published 'imaginary ethnography', whereby observers could project preconceived notions onto Others and then report them as empirical evidence". ' Moreover, encyclopedia entries do not usually indulge in irreverence, as does Hoerder in his discussion of the powerful attraction that Rome held for prostitutes. ${ }^{2}$ Finally, few encyclopedia authors take such delight in bringing little-known pieces of information to

I. Hoerder, Cultures in Contact, p. 36.

2. Ibid., p. 90. 
light, such as the fact that "around $900 \mathrm{CE}$, ibn Khordadbeh, postmaster of the Arab province of al-Jibal in Persia, compiled his eight-volume Book of the Roads and Countries as a guide for the postal system. He described roads and sea routes as far as Korea, giving detailed directions, distances, weather conditions, and road security". ${ }^{3}$ Hoerder was pressed to shorten this manuscript, yet some of this fascinating detail was allowed to survive, and as a consequence these nonencyclopedic materials make Cultures in Contact a pleasure to read.

There is a tension inherent in this study. On the one hand, Hoerder's knowledge of migration and migration theory leads him to insist on the meso-level of social organization and the economics of migration, on migration systems, human contacts, regional economies, and families. Women are important; indeed, they are so important that there is not a man to be found in the collage of photographs on the dust jacket of the book. On the other hand, the kind of information available to the researcher on such a project seldom includes direct information on the meso-level human relations and economic shifts that are so important to the migration process as it is now understood. Available information (when one searches globally, and for a millennium's worth of evidence) rarely is of the quality and richness that such analysis requires. This disjuncture puts a heavy burden on the researcher, who must work very hard to extract information and inferences about contacts and connections from available case studies and an older literature. Hoerder is more than up to the task, but the tension between theory and available sources keeps the reader alert.

This tension also serves the study by highlighting the destructive aspects of forced migration, from enslavement in earlier times through the wartime displacements of the twentieth century. Hoerder's emphasis on community, the logic of relations, and the importance of local economies renders the absence of these connections in forced movements all the more brutal and disconcerting. One of the long-term lessons Hoerder deals out with great clarity is also embedded in this contrast between the communal nature of ordinary migrations and the brutality of forced movements: the intolerance that serves as the engine of expulsions, mass murder, and programs of ethnic cleansing is a plague in the history of our world because ignorance, incuriosity, and dehumanization prevent cultures from coming in contact. This is especially emphasized in the separation of cultures resulting from the expulsion of Muslims from southern Europe at the end of the fifteenth century, and the anti-Jewish pogroms and internecine strife among Christians that made for a bloody sixteenth century. The same is true of the I990s, a period of what Hoerder calls the "Un-Mixing of Peoples" that has produced a global apartheid. When cultures can and do 
come in contact, the world is a better place; when they cease to do so, it is a disaster for one and all.

Dirk Hoerder has achieved the enormous feat of moving a field forward by globalizing the study of human movements. He sees the world from the perspective of a Europe that has perpetrated a good bit of damage on the rest of the world, but has not been entirely alone in doing so. Hoerder's migrant workers are not only the laborers he knows so well (those who went to North America) but also the miners in the coalfields of West Bengal, and the some 20,000 Egyptian fellabeen who dug the Suez canal. He has given the history of migration a new starting point and a challenging new context.

What if we were to take a global perspective literally, as Leo Lucassen suggests, and investigate human mobility worldwide, applying the same analyses to all areas? This is a most stimulating idea. The considerable difficulty of translating extant concepts to cultures in which they may not apply, Dipesh Chakrabarty indicates in Provincializing Europe, promises to raise a host of fascinating, although not insoluble, problems. ${ }^{4}$ What does harvest migration mean if one cannot get home afterwards? In a culture where the word for the breaking of ties is used for divorce and for being fired from one's job, how does one express leaving home for good? What does marriage migration mean in cultures where this happens in childhood or early adolescence? What difference would this make to the study of it? A host of exciting and thorny questions await us. 


\title{
Migrations in Latin America: A Crosscultural Perspective
}

\author{
MARCELO J. B ORGES
}

General studies of migration in Latin America are mostly limited to national cases, and analyses that link the region to global patterns of migration are rare. Regional studies that have gone beyond national boundaries include Magnus Mörner's Adventurers and Proletarians (first published in the I970s) and the recent compilations by Boris Fausto (1999) and Baily and Míguez (2003). ${ }^{\mathrm{I}}$ Thematically, these analyses focus mostly on European migrants (with some studies of Japanese and Middle Eastern migrants); chronologically, they deal with the so-called period of mass migrations (late nineteenth century and early twentieth century). Traditionally, migrations during colonial times and the movements of African slaves across the Atlantic and within the New World have been analyzed separately. ${ }^{2}$ As a result of these parallel developments, an informal specialization emerged in Latin American migration scholarship: migration historians analyze the labor migrations of the nineteenth and early twentieth centuries, colonialists deal with movements during Spanish and Portuguese rule, and historians of race and slavery study forced migrations from Africa. Another standard practice separates migration scholarship along disciplines: while historians analyze migrations until the I950s and focus on international movements, sociologists and anthropologists study later migrations and focus on internal and regional movements within Latin America. ${ }^{3}$

In Cultures in Contact, Dirk Hoerder presents a global and integrated view of migrations in the last millennium, in which regional patterns of geographic mobility are analyzed in relation to other spaces and in a broad

I. Magnus Mörner, with the collaboration of Harold Sims, Adventurers and Proletarians: The Story of Migrants in Latin America (Pittsburgh, PA [etc.], 1985); Boris Fausto (ed.), Fazer a América: A Imigração em Massa para a América Latina, Ist edn (São Paulo, I999); Samuel Baily and Eduardo Míguez (eds), Mass Migration to Modern Latin America (Wilmington, DL, 2003). 2. For example, Ida Altman and James Horn (eds), "To Make America": European Emigration in the Early Modern Period (Berkeley, CA, I991), and Nicholas Canny (ed.), Europeans on the Move: Studies of European Migration, I 500-I 800 (Oxford, 1994).

3. This division of labor is illustrated by the recent synthesis of immigration in Argentina by historian Fernando Devoto, in which the analysis of European migrations is complemented by an appendix about migration from neighboring countries, written by an anthropologist; Fernando Devoto, Historia de la inmigración en la Argentina (Buenos Aires, 2003). 
historical context. With different degrees of coverage, the analysis of migrations in Latin America spans from the late I 400 s to the late twentieth century, focusing on several historical periods and specific migration systems: the Iberian conquest and colonization of the Americas, including compulsive migration from Africa; nineteenth- and twentieth-century proletarian migrations across the Atlantic and the Pacific; regional systems of migration within Latin America after the r960s (with Argentina and Venezuela as the main destinations); and migration from Latin America to North America and Europe for economic and political reasons during the second half of the twentieth century. By considering the varied migratory movements to, from, and within Latin America across time and linking them to global developments, Hoerder breaks traditional disciplinary specializations and moves beyond artificial divisions, providing a more balanced approach.

One of Cultures in Contact's main themes is the systematic exploration of the cultural dimensions of geographic mobility and the redefinition of the "other" created by changing crosscultural interactions. The reader is presented with a full range of possibilities, from acceptance and inclusion to violence and dislocation, and a rich and carefully woven account of the varied factors behind shifting perceptions of self and other among migrants and the receiving societies. Hoerder adopts a human-centered approach that privileges migrants' creative coping and accommodation without losing sight of larger forces and limitations.

The Iberian conquest of the Amerindian civilizations in the late I $400 \mathrm{~s}$ and early I soos and the subsequent process of colonization provide the first critical juncture to examine the nature of cultural interaction and society formation resulting from free and forced migration to Latin America. The balance seems to be negative. It is characterized as a break with a previous period of intercivilizational contact and the beginning of another one in which curiosity gave way to profit and domination, and whole cultures were destroyed. ${ }^{4}$ Two main migration systems emerged from the European conquest: in the tropical zones, the natives resisted and forced labor was imported from Africa (and later Asia); in the moderate zones, European settlers pushed First-Nation peoples back and free migrants arrived in large numbers.

The most comprehensive analysis of migration in this period is devoted to the many forms of forced labor migration during the colonial period, including the different uses of Amerindian labor and the forced migration of African labor. The chapter on African slavery compares Spanish, Portuguese, and Anglo-American systems. In contrast, the previous analysis of conquest and European colonization treats the Iberian and Anglo-French worlds in separate chapters. In spite of the early emphasis

4. Hoerder, Cultures in Contact, p. Io9. 
on "the destruction of cultures", the characterization of postconquest societies stresses the emergence of hybrid cultures, which resulted from what Hoerder calls "ethnogenesis", the creation of a new population out of many backgrounds. In comparison with Anglo-America, the new Latin American societies were characterized by a flexible construction of ethnic and racially mixed groups linked to socioeconomic power, color, and appearance, which resulted in different possibilities for social mobility.

European migration to the Americas increased in the nineteenth century. Hoerder identifies a dual pattern during the late colonial period, from southwestern Europe to Central and South America; and from northwestern Europe to North America, which merged into a single Atlantic system during the late nineteenth century. In the discussion of intercontinental systems of migration during the nineteenth and early twentieth centuries, however, the movements to North America and South America are treated separately. The section on North America deals with migration from Europe, Mexico, and the Caribbean, as well as frontier expansion and the internal migration of African Americans. The section on Latin America focuses on immigration to Argentina, Brazil, and the Caribbean. The latter emphasizes the "dependent" character of Latin American economies, but there is no clear link between the economic characteristics of the region and immigrants' experiences. As other studies show, the type of economic activities and labor markets in the countries of immigration influenced migrants' destination selections and their economic opportunities and possibilities of socioeconomic adaptation. ${ }^{6}$ Similarly, Hoerder states that "self-selection of migrants channeled people according to their social profiles and the receiving society's economies", 7 as seen by the influence of cultural proximity, previous migratory experiences, and demographic factors.

Migrants' access to labor markets across the Atlantic (and within Europe) are discussed in the introduction to the section on "proletarian mass migrations". Labor markets in the countries of immigration were "stratified and segmented"; only native workers and a few skilled migrants had access to competitive jobs. Regarding competition with native workers, Hoerder states that in markets that "were stratified according to skills and language competency and segregated by gender, ethnicity, skin color, and, sometimes, religion", only some segments of the market were open to the newcomers. ${ }^{8}$ The examples that illustrate these points come from North America and Europe. While Cultures in Contact has

5. Ibid., p. I 32 .

6. For the case of the Italian labor diaspora, see Samuel Baily, Immigrants in the Lands of Promise: Italians in Buenos Aires and New York City, I870 to I9I4 (Ithaca, NY [etc.], I999), and Donna Gabaccia, Italy's Many Diasporas (London, 2000), ch. 3.

7. Hoerder, Cultures in Contact, p. 359.

8. Ibid., p. 345. 
moved clearly beyond North America and North Atlantic exceptionalism, sometimes their experiences are presented as the general pattern.

A crosscultural perspective might produce a more varied picture. Did market segmentation work the same way in all the immigration countries of the Americas? What happened in countries, such as Argentina and Uruguay, or regions, such as southeastern Brazil, where immigrants formed the majority (or at least a large proportion) of the working population? For example, in I9I4, immigrants made up over two-thirds of the active population of Buenos Aires and about half of its total population. ${ }^{9}$ Further, what was the situation in labor markets that gave preference to immigrant workers over native-born ones? Brazil presents an interesting case: at the national and regional level, governments sought to replace freed slaves with European immigrants; therefore, in this segmented market, immigrants had an initial advantage over large sectors of the local working population. This was true in the rural sector of coffee production as well as in the industries of São Paulo, where immigrants and their descendants were hired at higher rates than Afro-Brazilians. ${ }^{10}$

The preference for immigrant laborers over native-born ones is linked to another significant topic: the different perceptions of immigrant workers in the countries of the Americas. As Hoerder notes, as a result of "Latin American color gradation, working-class immigrants from Europe, considered more white, held a competitive advantage over local workers of mixed origin, considered more Colored". ${ }^{\text {II }}$ There were also cultural considerations and the significant role nineteenth-century and early twentieth-century Latin American elites assigned European immigrants in their plans for modernization (understood as both economic development and a "whitening" of the population). ${ }^{\mathrm{I} 2}$ As other studies show, at the turn of the twentieth century, when European workers mobilized against labor injustice and participated in the emerging labor movements, the same elites reconsidered their views of the native workers (but this reconsideration did not mean a significant change in immigration policy).

In Brazil, some members of the elite also began to look beyond Europe, to Asia; Japanese workers were seen as a solution. In the I890s, a Japanese envoy arrived in Brazil and, in Jeffrey Lesser's words, "sold Japanese immigrants as everything Europeans were not: quiet, hard-working, and

9. Devoto, Historia de la inmigración, pp. 294-300.

I0. George Reid Andrews, Blacks and Whites in São Paulo, I888-1988 (Madison, WI, I991).

I I. Hoerder, Cultures in Contact, p. 357.

I2. Richard Graham, The Idea of Race in Latin America, 1870-1940 (Austin, TX, 1990). See also the crosscultural analyses in Baily, Immigrants in the Lands of Promise; and Donna Gabaccia, "The 'Yellow Peril' and the 'Chinese of Europe': Global Perspectives on Race and Labor, I915-1930", in Jan Lucassen and Leo Lucassen (eds), Migration, Migration History, History: Old Paradigms and New Perspectives (Bern, I997), pp. I77, I96. 
eager to become Brazilians". ${ }^{13}$ About 250,000 Japanese arrived in Brazil between 1908 and 1970. Although perceptions of these immigrants in the receiving society varied, a complex reconfiguration of ethnic and racial categories took place, resulting in a reclassification of Japanese as nonAsians, as a model minority, or as equal to or above Europeans. Along with Japanese workers, trans-Pacific migration to Latin America included contract migrants from China, but they were not seen in the same positive light.

Labor migrations across the Atlantic and the Pacific set forth a complex process of acculturation, and created new transcultural identities in the context of the consolidation of nation-states. Hoerder explains:

Skin color came to serve as a marker not just for colonized peoples. British, French, and Spanish peoples and German respectively had primary states as Whites, while peoples from the periphery, except Scandinavians or "Nordic" peoples, were not White: Italians were "swarthy" or "olive"; Eastern Europeans were termed "dark", and the Irish had yet to become White. ${ }^{14}$

Yet the examples presented above suggest that ethnic and racial categories could be manipulated and changed considerably in the main countries of immigration in the Americas. These strategies become more clear in comparative perspective. At the same time that Europeans were racialized as potential criminals (for example, in some turn-of-the century naturalist novels), Japanese immigrants in Brazil were presented as having the traits European immigrants were supposed to have, and for which the Brazilian state had invested in sponsorship. Moreover, influenced by shifting socioeconomic, cultural, and political factors, perceptions on immigrant origins and ethnic identities may also change over time and across generations. The turn of the twentieth century is witnessing one such trend in Latin America, with a growing movement of descendants of European and Asian migrants to Europe, Japan, and Israel. ${ }^{\text {Is }}$

Systematic crosscultural analyses of migrants' experiences and adaptation in the immigration countries of the Americas (and with other destinations worldwide) would shed more light on these issues. This approach raises the question of the appropriate units of analysis. Hoerder uses a variety of units (nation-states, regions, localities, families, individuals). His emphasis is on a meso-level analysis, in which larger socioeconomic and political forces meet local and family dynamics and decisions. In the case of European and Asian migration to the Americas, adaptation and acculturation are largely analyzed at the national or

I 3. Jeffrey Lesser, Negotiating National Identity: Immigrants, Minorities, and the Struggle for Ethnicity in Brazil (Durham, NC [etc.], 1999), p. 82.

I4. Hoerder, Cultures in Contact, p. 362.

I5. See, for example, Arnd Schneider, Futures Lost: Nostalgia and Identity among Italian Immigrants in Argentina (Oxford, 2000). 
subregional level (North America versus Latin America). More comparative studies are needed to illuminate the diverse immigrant experience at the meso-level. The proper unit of analysis would depend on what aspects are under scrutiny. While the impact of policies and cultural perceptions can be examined by looking at states and cultural traditions, socioeconomic adaptation or the socioeconomic impact of immigration would benefit from regional and local approaches. Since, by its very nature, centuries of migration have connected the Americas with the world, hemispheric patterns and experiences can only be fully understood in a wider context. Cultures in Contact provides a broad historical and geographical framework in which to situate these studies and show the possibilities and rewards of this global approach. 


\title{
Some Comments on Canada, Women, Gender, and Race
}

\author{
FRANCA IACOVETTA
}

Dirk Hoerder's Cultures in Contact is a human-centered and humane approach to world systems analysis that shows much sensitivity to gendered experiences and relations. Migration historians have long known that peoples have always been on the move. This "heavyweight" book effectively demonstrates that central thesis - that the primary, defining feature of human life is mobility. I, too, was struck by Hoerder's ability to link historic events to global and regional migration flows within and across geopolitical and cultural borders, while also remaining mindful of how men, women, and children moved, encountered others, lived, adapted or failed, and intermingled. Hoerder details the directions and dynamics of peoples in interaction with each other, considering economic and geopolitical factors as well as personal, family, and household dynamics, sites of production, reproduction, and consumption, and cultural interaction. And his efforts to develop "a material-emotions framework" helps to bring a sense of humanity - even a sense of the intimate, and, on occasion, the sensual - to a world systems framework that can produce important but dry-as-dust history.

For Canadianists, who are accustomed to seeing Canada all but ignored (or subsumed into the US) in world history texts, it bears stressing that Hoerder takes Canada seriously. ${ }^{\mathrm{I}}$ To note, then, that the Canadian coverage is uneven (for example, the discussion of the nineteenth century, a significant era of migration, is brief and deals mainly with the Irish), is merely to underscore the obvious: even a large volume like this one cannot include everything. The book also offers the wider context for various groups of migrants who entered Canada, such as indentured servants from eighteenth-century France and Asian migrants who migrated to North American destinations in the nineteenth and twentieth centuries.

Rather than draw more lists, I will note the absence of a specific "Canadian" example - the Beothuk of Newfoundland - since it offers an exception to Hoerder's central theme of "contact" and "co-mingling". Briefly, the Beothuk encountered Europeans in the late fifteenth or early sixteenth century, when English, French, and other European fisherfolk

I. Dirk Hoerder, Creating Societies: Immigrant Lives in Canada (Montreal, 1999) writes the history of Canada through the life writings of its many immigrants. 
began to make their seasonal voyages abroad, doing so probably before the arrival in I 497 of Newfoundland's (and Canada's) official “discoverer", John Cabot (or Giovanni Caboto). We know that European contact produced horrific consequences for the First Nations - the decimation of their numbers and assault on their families and cultural traditions - but also that they survived to the present day; today's political struggles reflect that fact. Yet, the Beothuk, within a relatively short period of European contact, disappeared as a people. The last known surviving person was Shawandithit (Nancy), who died from tuberculosis in I 829; she had given anthropologists critical information about her people's oral history and traditions.

Whereas many Amerindians were initially curious about, and some initiated trade with, the European arrivals, the Beothuk, a semi-nomadic people who practiced a seasonal-based economy that combined fishing on the coast in spring and summer with winter game-hunting in the interior, largely avoided such contact. It appears that they chose to withdraw from the Europeans on the coast because they could acquire the desirable foreign items (metal pots, iron hooks) by raiding in the off-season the fish stations set up by European fishermen intending to return the next season. Then, as the Europeans gained greater control of the coastal areas, the Beothuk lost a critical (coastal) source of sustenance and could not survive by living exclusively in Newfoundland's inhospitable interior. ${ }^{2}$ Most starved to death.

In raising this example, I wanted, as I said, to note a contrasting and Canadian pattern not discussed in the book, but also to ask Hoerder whether such examples make a difference to his framework of contact and interaction. Also, how might we learn whether emotions, to return to Hoerder's "material-emotions" framework, played any role in the Beothuk's response to the Europeans' arrival? To date, the explanations remain largely in the realm of the economic and geographical. Is there something in the oral history of this people, the history culled in part from the final surviving women, that might tell us? These are difficult, but also important, questions.

Second, Hoerder pays careful attention to women and heterosexual relations and integrates feminist and gender scholarship. He considers how gender inequality and gender systems of power constrained many women's role in migration, noting, for example, that their primary responsibility for children and other family members limited their options to migrate. He also addresses the differences among women and the range of women on the move, or forcibly moved. His discussion of white women in the context of empires/colonies examines their assigned roles as

2. On the Beothuks, see, for example, Ralph Pastore's work, including "The Collapse of the Beothuk World", Acadiensis, 19:7 (1989), pp. 52-71. 
"daughters" of the empire - as civilizing agents/colonizing agents - and also the colonizers' preoccupation with mixed-race sex, thereby drawing effectively on recent postcolonial and gendered histories of women and empire. ${ }^{3}$ He also notes the more exceptional women who had the independent means to move and negotiate new relationships in new contexts, whether for good or ill. His various discussions of prostitution, and of sex trade workers, as well as picture brides, seek to capture the multilayered dynamics involved.

Overall, though, the emphasis is on positive (heterosexual) relations, suggesting that Hoerder, being a "humane" historian, sought to accentuate the positive in male/female personal and sexual encounters. True, comparisons are drawn between consensual and coercive sexual encounters and relations: note the grim discussion of contemporary sex tourism. But we do read a lot about "co-mingling" and about men who "consorted" with women (as in fur traders with Native women). No doubt, Hoerder chose a "social scientific" term like co-mingling as a way of conveying a range of relationships, from the positive to the exploitative and violent. Also, he is correct to note that co-mingling, in whatever context, often produced a new mixed progeny and people. References to migrant men "consorting with women" similarly suggests that he is describing a range of practises. However well-intentioned, the use of these terms (can they truly be "neutral" ones?) nonetheless means that there is comparatively little explicit discussion of the rape of women and children, domestic violence, and other abuses. If we rarely use words like rape, violence against women, and violation of women's bodies, do we risk (re)masking a gendered history that has only recently begun to be told as an integral part, not an unfortunate by-product of, or side-show to, the history of migration, imperialism, colonialism, war, and many other major developments in human history?

In showing respect for women's agency, as Hoerder clearly does, we need also to avoid exaggerating that agency to the point of downplaying the continuing force of patriarchy: this is a delicate problem that feminist historians too have not yet fully resolved. On the other hand, I ask if Hoerder has any advice, or predictions to make, regarding a new womancentred migration project being initiated by Donna Gabaccia, currently called "for love of country". Using the Italian case, it will examine how women migrants acquired national identities (one working hypothesis is that they often did so for different reasons than did men), exploring in particular the role that emotions and intimacy played in the process. Given Hoerder's treatment of such themes, would he agree, for example, with the following hypotheses? Citizenship is a male-defined and male-imposed

3. For example, Margaret Strobel, Gender, Sex and Empire (Washington DC, I993); Mrinalini Sinha, Colonial Masculinity: The "Manly Englishman" and the "Effeminate Bengali" in the Late Nineteenth Century (Manchester, 1995). 
concept that renders women irrelevant; women were far more likely than men to develop relationships to the nation-state as a result of their links to and relationships with children, relatives, and community.

Of course, Hoerder's Cultures in Contact offers yet another challenge to - indeed, hammers yet another nail into the coffin of - national histories. But will many Canadian historians read the book and take up its central messages? The current situation is both promising and not. Canadian historians were not in the vanguard of efforts to internationalize national history, though, of course, international agendas were critical to the "new" social history of women, labor, and immigration. Furthermore, women's, labor, immigrant, family, and Aboriginal scholars have offered compelling critiques of dominant liberal narratives of Canada's history. Studies of slavery, First Nation women, residential schools, Chinese workers and head taxes, the "Hindu woman question", African-Canadian women, and Japanese-Canadian internment have challenged Canada's image as the "peaceable kingdom", a "race-less" country free of US Jim Crowism, and an enlightened "nation of immigrants" with a long history of respecting cultural diversity. Building on the new scholarship, Canadian social historians of various specialties have recently written more "bottomup" and inclusive histories of the "Canadian peoples", and adopted more explicit gender and race critical analyses. In women's history, a shift from an earlier "global sisterhood" to one of "unequal sisters" paradigm made more room for Canada's many immigrant, ethnic, and racialized peoples (households and communities).

Despite all this activity, the dominant liberal narratives have been modestly revised, the history of migrants and immigrants retains the status of a "sub-field", and the Canadian profession remains overwhelming white. Also, at the same time as books like Hoerder's continue to show the value of writing people's history that are less nation-bound, in Canada, the recent right-wing charge that social historians "killed" Canadian history by replacing the grand tales of political, diplomatic, and military progress with studies of the so-called private or trivial has led to many important claims to the contrary. But, alas, in some cases, it has also meant a curious return to a more "border-bound" Canadian history, one that fails to question the categories of the nation. Among the loud voices calling for "beyond border" or "transnational" histories of Canada's peoples are those of feminist social scientists, who study "Third-World" migrants and immigrants in Canada, and postcolonial and race-critical scholars, including historians, interested in the links between gender, race, and nation-building. Ever the optimist, I hope that books like Hoerder's Cultures in Contact will help us to move from the questions, "Who Killed or saved Canadian history?", to "Who is internationalizing it?"! 
Toronto has long been a city of immigrants, and today it continues to be so, but with an increasingly wide variety of immigrants and growing numbers of "not-white" immigrants from India, Hong Kong, the Caribbean, and elsewhere. Transnational families and networks are not just creations of the present "postmodern" world, as migration historians have shown, but many contemporary immigrants do have a more active and ongoing relationship with relatives, culture, and society back home. This is evident in our multiracial student body at the University of Toronto: large numbers of students who belong to more recent migration waves from places as diverse as Portugal, Hong Kong, the Middle East (Jewish, Christian, and Muslim), and Jamaica "go back and forth" frequently. Notable exceptions are refugees. Hoerder's book could help us teach the history of the global in the local (Toronto).

Fostering diversity is a current administrative initiative at my university. Amid the frustratingly vague language, there is the message that all programs and departments are to diversify in every possible way and also an optimistic faith that our multiracial student body will encourage faculty to embrace diversity. The most promising thing for historians is the possibility of creating a Centre of Diaspora Studies, one that will hire specialists of diasporic peoples and teach the history of the world's mobile peoples. As part of that process, historians of Canada (and of Toronto), including myself, hope to design courses that explore "the global in the local - Toronto". Hoerder's fine Cultures in Conflict will be a great help.

issue of gender and migration in Canada, see Marlene Epp, Franca Iacovetta, and Frances Swyripa (eds), Sisters or Strangers? Immigrant, Ethnic and Racialized Women in Canadian History (Toronto, 2004). On internationalizing Canadian history, see Ruth Pierson's important interventions, including "Experience, Difference, Dominance and Voice in the Writing of Canadian Women's History”, in Karen Offen, Ruth Roach Pierson, and Jane Rendell (eds), Writing Women's History: International Perspectives (Bloomington, IN, I99I). 


\title{
The Recurring Problem of Chinese Ethnicity in World Migration
}

\author{
Madeline Y. Hsu
}

Cultures in Contact covers a millennium of world migration characterized by all the complexity suggested by the author's ambitious approach. "The combination of a 'systems approach' with a human-agency approach proposed in this study attempts to link the level of states and continents to migrant-sending families and migrating individuals via the mesolevel of the regions out of which migrants come and into which they seek to go.” I Hoerder traces the choices of individual men and women, as they move through multiple layers and regional systems of migration, while engaging in networks and practices of migration of varying levels of complexity and permanence. Hoerder masterfully integrates the structuring forces of political hierarchies and economic inequalities with the ideological values attached to migrants, and the fluidity of the cultural processes that proceed from encounters between different groups. Complexity characterizes these many relationships:

On the macro level, migration systems connect two distinct societies, each characterized by degree of industrialization and urbanization, by political structures and current policies, by specific educational, value, and belief systems, by ethnic composition and demographic factors (age structure, marriage patterns, dependency ratio), and by traditions of internal, medium-distance, and long-distance migrations. ${ }^{2}$

To do justice to such big questions spanning such broad expanses and sweeps of time, Hoerder has produced, literally, a very large book.

The breadth of material covered by Hoerder permits us to contextualize patterns and relationships that have often been described in morally freighted, accusatory terms. The mobility of migrants brings into contact and frequently bitter conflict the contrasting agendas of nation-states, economic systems, ethnic communities, and family units. As various systems and interest groups struggled against each other for dominance and survival, they produced varying narratives of blame, accusation, selfjustification, and triumph that encoded the meaning of migrants and those that they either oppressed or were oppressed by in very different and

I. Dirk Hoerder, Cultures in Contact, p. 564.

2. Ibid., p. 16. 
perhaps equally distorted ways. The tendency of monographs and other forms of migration studies to focus on particular sites and particular ethnic groups fosters tendencies toward recrimination and triumphalism, as scholars and writers advocated on behalf of their chosen subjects. To this day, the subject of migrants and their impact upon national unity and strength remains highly politicized and subject to debate.

The ambitious scope of Cultures in Contact grants us a more neutral space from which to evaluate, if you will, the degrees of damage and exploitation rendered by various migrating groups during the past $\mathrm{I}, 000$ years. For example, Hoerder's broad-ranging discussion of slavery underscores that it is an economic and social practice that has a multitude of forms and social meanings, and has been practiced by many different cultures under a host of circumstances. Many peoples have been complicit in the enslavement of others.

Slavery and forced labor had been part of Inca and Aztec as well as Asian and African societies. Within European and Russian-Siberian societies, serfdom, debt peonage, the forced labor of soldiers, and hard labor in punishment for crimes existed. All of these involved lower social classes or castes, prisoners of war, or criminals; others involved raids on less powerful neighbors - whether they were states, small societies, or clans - in order to capture laborers. ${ }^{3}$

This broadly comparative account reveals that these forms of slavery were not as binding, hierarchical, or damaging as that of the African slave trade, initiated in the I 440 s by the Portuguese, who were later joined by Dutch and British in working jointly with African traders (p. I25). This more nuanced depiction does not remove the incendiary burden of racism, or dispel twenty-first-century abhorrence of the plantation system, but it does remind us that European colonists were not alone in committing this form of exploitation. Hoerder does argue, however, that African slavery was more significant than other manifestations, as "[c]olonial enslavement placed Europeans over Others, and the color White over any other color". ${ }^{4}$

It is because he offers this comparative analysis of exploitation and warfare that Hoerder is able to load his guns more fully in attributing the most blame to European imperialism, for causing the greatest levels of harm and human suffering. Cultures in Contact recounts many instances of cruelty and inequality in a wide-ranging sweep that leaves few groups entirely free of guilt. Hoerder can deflect somewhat charges of bias against European colonial capitalists because he comes to the judgment that their crimes were more heinous, only after acknowledging the abuses wrought by other empires. He thereby underscores the ways in which their violations simply do not compare with the depredations implemented by the expansion of European capitalism that began in the fifteenth century.

3. Ibid., p. 235 .

4. Ibid. 
According to Hoerder, these inequalities persist in the form of a global apartheid that structure, by race, economic exploitation, and differential access to opportunities.

Hoerder's ranking of exploitation parallels the racial formations theory developed by Michael Omi and Howard Winant, in which they argue that there are gradations of racism, depending on the degrees to which the act of perceiving differences on the basis of race contribute to structures of domination or inequality.5 In a similar vein of logic, Hoerder charges European imperialism as the key agent of inequality and exploitation in a world still recovering from the effects of its colonial past. Despite the many individuals and communities and cultural transformations brought together in this book, European colonialism emerges as the most harmful pattern of migration and contact in world history.

Hoerder's emphasis on this dichotomy between white racism and colonial power produces something of an imbalance in his treatment of other regional and cultural powers that did not become global villains. For example, although China and the Chinese receive frequent mention, Cultures in Contact neglects the long-term impact of China's ongoing geopolitical presence in the Asia-Pacific region. Chinese migration offers a telling contrast to the narrative of European conquest and imperialism that dominates Cultures in Contact. Over the course of two millennia, China has been a compelling presence through sheer size, population, wealth, and political might.

The expanding reach of China's reputation for power and wealth may be understood through a minor error in Hoerder's text. The famous Venetian, Marco Polo, is described as "the epitome of the traveler", and proof of the vibrancy of thirteenth-century Eurasian trade (p. 34). The latest Chinese studies scholarly consensus, however, is that Marco Polo never went to China and that the account of his travels was based on other travelers' tales and guides current at the time. ${ }^{6}$ This does not undermine much of the significance Professor Hoerder attaches to Marco Polo - for regular Eurasian travel and high levels of contact were still needed for Marco Polo to write his tale - but it does place a different light on European consciousness of China. That is, China's wealth, power, and general fabulousness loomed large enough in the consciousness of Europeans of

5. See Michael Omi and Howard Winant, Racial Formations in the United States: From the I 960 s to the 1990s (New York, 1994, 2nd edn).

6. See Frances Wood, Did Marco Polo Go to China? (Boulder, CO, 1996). Wood offers a variety of evidence, including the absence of anybody who could be construed as Marco Polo from the imperial records. If Marco Polo had attained the bureaucratic level claimed in his book, he would appear in Chinese historical accounts. She also notes his failure to mention prevalent practices such as foot-binding or tea drinking. Much of Polo's account are believed to derive from Arabic sources. 
Polo's generation and later, that such a tale would be concocted and would resonate for centuries thereafter.

Despite its power and wealth, China did not embark on a path of global conquest or dumping of excess population in the manner of Europe. For much of the past millennium, emigration from China has been illegal, apart from strictly demarcated imperial missions and ill-fated naval forays. The grandeur of the exploratory missions led by the Ming dynasty eunuch, Zheng Ho (I405-I433), to India and East Africa indicate the technological prowess and daring of the Chinese. 7 But for its nation-building efforts during the late Qing (I644-I9II), and early Republican period (I9I21949), when overseas support was cultivated, the Chinese state has remained a landbound power that disavowed responsibility for those Chinese who ventured overseas.

The ongoing waves of merchants, adventurers, entrepreneurs, students, artists and artisans, and workers who have defied imperial bans to seek prosperity and security abroad have attained success and stability without the backing of a mighty state, and oftentimes in spite of China's looming shadow. The vast majority settled into middle- and working-class lives, and depending upon local government dictates, over generations either disappeared into local populations or established acculturated ethnic communities. The most visible of Chinese overseas, however, became economic tycoons, controlling large sectors of Southeast Asian economies, far out of proportion to their numbers. ${ }^{8}$ Economic prominence, however, has been largely divorced from political influence except in the rare instances when Chinese have become the majority settlers, as in Singapore, or have been permitted to intermarry into indigenous elites, as in Thailand.

Chinese overseas face the tricky situation of originating from a highly visible world power which, for the most part, has disavowed responsibility for them. By and large, however, Chinese overseas have, at worst, been considered traitors and, at best, advised to settle and assimilate in their new homes. In the present, Chinese overseas are encouraged to invest in China and introduce intellectual innovations, but are not courted for their political loyalty, and are in fact encouraged to naturalize and gain citizenship in their countries of settlement. Despite this disavowal of political goals, akin to colonization through exported persons, China's eminence continues to loom in ways that very much affect the lives of

7. Columbus's largest ship measured only 40 metres in length with roo sailors; Zheng Ho's largest ship was I40 metres and accommodated about I,000 sailors, soldiers, and servants; Hoerder, Cultures in Contact, p. I $3 \mathrm{I}$.

8. The relatively higher levels of Chinese entrepreneurial success have been explained in various ways, some with reference to the extensive global networks that advantaged Chinese in trade and industry, greater exposure to entrepreneurship and uses of capital while in China, as well as the usefulness of an outsider entrepreneurial class in the state-building processes of southeast Asia comparable to the roles played by Jews in eastern Europe. 
Chinese overseas and perceptions of their relations to China and the prospect of Chinese empire. Chinese overseas find themselves legally demarcated and liable to attacks when political and economic crises arise.

Chinese experiences in Indonesia demonstrate their vulnerability to racially and politically generated fears, despite persistent efforts to settle peacefully. In the Dutch East Indies in I740, about two-thirds of the I 5,000 Chinese on Batavia were killed in a massacre by Europeans, fearful of the more numerous Chinese. Recognizing that Chinese were vital to economic development, the Dutch invited the Chinese to return, but imposed discriminatory policies. After Indonesia became independent, the Chinese continued as a demarcated class, thereby becoming highly visible targets after the 1965 attempted communist coup. Subsequent government attempts to assimilate Chinese through enforced naturalization, name changes, and elimination of open signs of Chinese ethnicity, such as newspapers, religion, schools, festivals, and so forth, fell short, as otherwise invisible ethnic Chinese continued to be labeled in their ID cards. To the shock of middle- and working-class ethnic Chinese, who had lived for decades as Indonesians, blame for the 1998 economic crises and failures of the Suharto regime landed on their doorsteps. Chinese were more accessible targets for public outrage than the corrupt leaders and their military backers.

Even Thailand, famous for its absorption of Chinese to the level of the royal family, endured its bouts of anti-Sinicism. In Thailand's tremendous efforts to modernize in the early twentieth century, the Chinese became targets in royal attempts to consolidate national cohesion by ascribing the alarmist label, the Jews of the Orient. Such assertions were intended to reinforce the state rather than incite public racism, but tensions arose over competing jus sanguinis claims of citizenship, aggravated by the international depression of the I930s. During the I930s and I940s, the Thai government passed a rash of anti-Chinese laws intended to hasten assimilation by imposing limits on education, special fees and taxes, and banning Chinese from particular businesses and professions. These assimilation efforts would succeed in part because relations with China remained almost totally dormant between the i950s and the I970s.

Fears of Chinese empire and colonization have affected not just southeast Asian states but the European-dominated entities of Australia, New Zealand, and across the Pacific to Canada, Mexico, and the United States as well. The United States, in particular, justified passing its first immigration restrictions in part from fears that Chinese would battle Euro-Americans for control of the west coast. The United States also pressured Canada and Mexico to impose similar constraints, in order to improve America's ability to police its land borders against the Chinese "threat". Although the Chinese Exclusion law was repealed in 1943, widespread fears of communist China thrived during the Cold War. Two 
decades after the normalization of relations, however, scaremongering about Chinese empire and its overseas minions played to wide press in the presidential elections of both 1996 and 2000, in the form of the John Huang campaign finance scandal and the persecution of the nuclear scientist, Wen Ho Lee. Politically motivated questioning of Chinese appeared in Representative Christopher Cox's I999 report to Congress with the implication that, "every Chinese visitor to this country, every Chinese scholar, every Chinese student, every Chinese permanent resident, and even every Chinese American citizen is a spy, potential spy, or 'sleeper agent', merely waiting for the signal to rise up and perform some unimaginable act of treachery".?

The threat of Chinese empire insinuating itself around the world through millions of sleeper agents, in the form of ethnic Chinese overseas, is an idea traceable to Sax Rohmer's Fu Manchu, and even further back to the Yellow Peril represented by Genghis Khan's Mongolian hordes. It is a shadow that bears no relevance to the daily realities of ethnic Chinese seeking the basic goals of prosperity, stability, and security abroad, yet it is a threat that reemerges with dismaying force in times of crisis requiring convenient scapegoats. It is also a recurring reminder that the racist hierarchies, so decried by Hoerder, are manifested in many different forms, and continue to persist because racial intolerance too often can be made to serve the interests of those in power.

9. See Lars-Erik Nelson, "Washington: The Yellow Peril", The New York Review of Books, 46:I 2 (I 5 July 1999), pp. 6-10, in which Nelson reviews Report of the Select Committee on US National Security and Military Commercial Concerns with the People's Republic of China, 1osth Congress, Report I05-85 1, 25 May i 999; quotation from p. 6. 


\title{
Migration: A Millennium of Meso-level Analysis
}

\author{
PATRICK MANNING
}

Readers of Cultures in Contact will surely note the remarkable care, patience, and comprehensiveness of the author's research and writing, as he explores the details of the past thousand years of migration systems throughout the world. These "migration systems" - the elements of Hoerder's analysis - consist of sets of origins and destinations of migrants, and include the paths and social adjustments of the migrants. The seventy maps mark the thoroughness and the originality of his assemblage of migratory movements: for instance, roughly twenty of them address Asia, and over fifteen address Africa.

Hoerder's analysis invites critical scrutiny, both at the level of individual migration systems and at the level of the author's overall argument. The narratives of localized migration are written forcefully enough to encourage specialists to debate them. Thus, in the African and Atlantic areas that I know best, I found points to debate and occasional small errors. Yet, I also found that he had skillfully located and surveyed the relevant scholarly literature, and argued (correctly, I think) that transatlantic slave exports brought a decline in the African population. ${ }^{\mathrm{I}}$ If specialists on other regions find a similar standard of narrative and interpretation sustained throughout the book, we will be able to conclude that Hoerder has provided not only his own synthesis, but a fine tool for further analysis. That is, the materials in Cultures in Contact may be taken as an adequate basis for further comparison and aggregation of migratory phenomena.

In addition to the strength of this hefty volume in matters of detail, the book is successful in addressing several large-scale questions in history. I offer four points of commentary on large-scale issues: on the book's place in new empirical research on migration; the author's interpretive choices; the book's place in the study of world history; and its place in theoretical frameworks for the study of migration.

I. Olaudah Equiano is listed as having been born in Benin kingdom, when in fact his autobiography gives his birthplace as the neighboring Ibo country; in a typographical error, the capital of Asante is attributed a population of 60,000 in the mid-tenth century when the nineteenth century is surely intended. On the other hand, Hoerder's review of the impact of slave trade on African population provides a thorough and sensible statement of this thorny issue; Hoerder, Cultures in Contact, pp. I48, I50-1 57. 
First, the book is surely empirically authoritative, as is indicated by the thorough and balanced survey of the available literature in its notes and bibliography. Yet one hardly dares label it definitive, since its field of research is rapidly producing new data and new perspectives. For instance, Adam McKeown's new work shows Asian migrations of the nineteenth and twentieth centuries to have been larger in volume than European migrations. ${ }^{2}$ These results not only change the balance of European and Asian migrations; they suggest that the causes of migration in the industrial era need to be reconsidered, since European causes are insufficient to explain the Asian movements. Cultures in Contact, in contrast, reflects the historic emphasis of the migration literature on European movements. Yet in following this emphasis, Hoerder is clear in presenting European migrations as examples of migration rather than as unique movements. His deft and detailed handling of migratory issues in the Ottoman Empire provides an effective bridge linking European to extra-European migrations.

Second, Hoerder's interpretive line emphasizes continuity and occasional transformation in patterns of migration. This point may be underscored by comparing the book with a parallel overview of migration, Migration in Modern World History, I 500-2000 (for which this reviewer is the principal author), a work about half the size of Cultures in Contact and produced in the form of a CD-ROM for an undergraduate audience. ${ }^{3}$ The thirteen units of the CD are each thematic and worldwide within a given time frame: the themes include encounter, religion and commerce, family, cultural movements, forced migration, nationhood, industrialization, empire, diaspora, refugees and genocide, and urbanization. Hoerder, too, explores each of these issues, but as subordinate topics in his narrative of regional migratory systems. The contrast is that the CD emphasizes that migration can be taken as a causal and illustrative factor underlying major themes and historical transformations, while the book emphasizes tracing the migratory systems themselves. The two approaches are distinct and in a sense complementary: Hoerder has chosen to give priority to documenting the generality of migration as a social phenomenon, and its changing character in response to social change.

Third, Hoerder's work provides a major statement of global historical patterns and, as such, needs to be set in context of other major interventions and debates in world history. Most obviously, the work should be linked to the recent analysis of "the Great Divergence" - the argument that the strongest Asian economies continued to grow to the end

2. Adam McKeown, "Global Migration I846-1940”, Journal of World History, is (2004), pp. I $55-189$.

3. Patrick Manning, Migration in Modern World History, I500-2000 (Belmont, CA, 2000). This $\mathrm{CD}-\mathrm{ROM}$ includes narrative and interpretive text; 400 primary and secondary documents in text, image, audio, and video format; and numerous questions and other resources. 
of the eighteenth century, and that British and other European economies came to exceed them in per capita and aggregate output and commerce only in a rapid change during the nineteenth century. ${ }^{4}$ This interpretation challenges the vision of Asian economic stagnation, and pushes the case for an integrated global economy back into the sixteenth century, especially through the example of the silver trade. Hoerder, meanwhile, follows the argument for a relatively unchallenged European dominance of the world economy from the sixteenth century.

Could Hoerder's narrative of global migration, with its emphasis on Europeans and migrations provoked by Europeans, be reconciled with the vision of the Great Divergence? Or, to put it differently, does the evidence on migration from the sixteenth through the eighteenth centuries sustain the vision of European dominance or of continued Asian growth? An extension of Hoerder's work, to conduct a thorough accounting and comparison of migratory movements, might help settle the question of whether the Atlantic was a more dynamic region than the Indian Ocean or the South China Sea in early modern times, or whether these regions were roughly parallel and indeed connected in their growth.

Fourth, Hoerder underscores the importance of "meso-level analysis" at key points of his introductory and concluding chapters. Between these explicit references, his meso-level analysis is implicit yet pervasive. Hoerder's meso-level, while clearly located between the micro and the macro, is distinct in character as well as in scale. For instance, Hoerder treats the "new economics of migration", with its focus on family-level rather than individual decisions, as micro-level rather than meso-level. The meso-level is characterized, not by units of analysis such as families, but by an "arena" of "economic regions and global migration options" - a space for the interactions of "kin and friendship networks", "regional economies", and information flows.

In implementing his approach and constructing his narrative, Hoerder inevitably includes a great deal of micro-level and macro-level analysis, ranging from individual decisions to state actions and macro-regional movements. At the same time, however, the author has systematically worked meso-level analysis into his portrayal of migration, as the following examples indicate. In describing Mediterranean slavery of the early second millennium, Hoerder identifies flows of slaves brought by

4. Kenneth Pomeranz, The Great Divergence: China, Europe and the Making of the Modern World Economy (Princeton, NJ, 2000); R. Bin Wong, China Transformed: Historical Change and the Limits of European Experience (Ithaca, NY, 1997); André Gunder Frank, ReOrient: Asian Economy in the Global Age (Berkeley, CA, 1998); Robert Marks, The Origins of the Modern World: A Global and Ecological Narrative (Lanham, MD, 2002); Sucheta Mazumdar, Sugar and Society in China: Peasants, Technology, and the World Market (Cambridge, MA, 1998); Prasannan Parthasarathi, The Transition to a Colonial Economy: Weavers, Merchants and Kings in South India 1720-I800 (Cambridge [etc.], 200I). 
the Genoese network based in the Black Sea port of Kaffa, by merchants of the Nile Valley, and by the victors in the religious wars of the western Mediterranean; he then traces the settlement of slaves, mostly female, in Genoese and other societies.' In the fifteenth-century Rhine Valley, he shows in text and a map the regional origins of locksmiths in Basel and coopers in Freiburg, revealing both their wide range and their concentration in nearby points of origin. ${ }^{6}$ Over a longer time-frame, he traces the generalization of the term "natio", from its medieval-era distinction among groups of Italian merchants in London and groups of scholars at the University of Paris, to a later category of "German" that might include Bohemians and Scandinavians.

Hoerder notes that "natio" implied an underlying heterogeneity, a heterogeneity he underscores with an extensive quote from Daniel Defoe's riotous comment on ethnic mixing in "The True-Born Englishman". 7 In a nineteenth-century example of meso-level analysis, Hoerder traces the life of Rosa to reveal patterns of Italian migration to the United States. She grew up as a foster child in the regional economy of Milan, pressed by her foster parents to marry, and then by her husband to migrate. At her destination in Missouri, she was associated with migrant miners and with the boarding house in which she served them. ${ }^{8}$ Finally, in an analysis of British daughters of empire, Hoerder begins with a macro-level observation of the surplus of females in England resulting from the preponderance of male out-migrants, then turns to meso-level analysis in South African destinations where the arriving white females found they were intended to replace black males as domestics. ${ }^{9}$

Could the meso-level analysis be focused on certain meso-level institutions? For instance, could the Latin American institutions of encomienda and mita be considered as meso-level institutions? Hoerder chose to define the meso-level not as a set of mid-level institutions, nor as a nexus for a mid-level theory of migration, but as a set of arenas for interaction of numerous influences. In sum, we can see that Hoerder's meso-level analysis adds variance in migratory situations, but does not add any new determinacy. That is, in this central analytical emphasis of Cultures in Contact, it is the work of a historian emphasizing contingency and specificity, rather than a social scientist searching out laws of behavior.

For all its emphasis on contingency and complexity, the book stops well short of portraying migration as a set of random events. While it is not a work of theory, it engages theory, and indicates how much more

5. Hoerder, Cultures in Contact, pp. $4 \mathrm{I}-42$.

6. Ibid., pp. $83-84$.

7. Ibid., pp. I $20-\mathrm{I} 22$.

8. Ibid., pp. 343-344; Marie Hall Ets (ed.), Rosa: The Life of an Italian Immigrant (Minneapolis, MN, 1970).

9. Hoerder, Cultures in Contact, pp. 427-428. 
developed theory will need to become before it can explain more than localized aspects of migration. Through systematic application of his historical framework, Hoerder is able to display the continuities and the regularities in a millennium of migratory patterns at the same time as he notes exceptions to the general rules. Cultures in Contact is therefore not just a title with a good ring to it, but a precise restatement of the author's meso-level vision of human migration. 


\title{
Where Do We Go from Here? New Perspectives on Global Migration History
}

\author{
LEO LUCASSEN
}

\section{INTRODUCTION}

This book is a milestone in the history of migration. Never before has anyone attempted to cover such a wide range, both in terms of time and space. In itself, this is not enough to constitute a good book of course, as is clear from the rather one-sided study by Potts, ${ }^{\mathrm{I}}{ }^{\text {which }}$ claims to cover the past five centuries. However, Hoerder's book is also an important step forward.

First of all because - in the spirit of Leslie Page Moch's Moving Europeans, a decade earlier ${ }^{2}$ - he uses a much wider definition of human mobility, which allows him to link the history of migration to mainstream social and economic developments over time. Migration then becomes more than just a product of inequality, repression, and racism, as in Potts's study. A second innovative aspect that makes this book an outstanding achievement is the way gender has been used systematically as a crucial category in describing and explaining human mobility and cultural fusion. Thirdly, Hoerder has tried very hard to avoid a Eurocentric/Atlantocentric interpretation of migration history, and to do justice to the semiautonomous migration patterns in other parts of the world. In doing so, he has unearthed a wealth of migrations, as well as modes of interaction between various migrants and their cultures, thereby shedding new and interesting light on the models so familiar to us in our American and European scholarly comfort zone.

Having read this book with great admiration, I want to use this contribution as an opportunity to develop some thoughts on the new roads that global migration history can and should take in the decades to come. For such an endeavor Hoerder's book is an ideal starting point, not only because it offers an excellent review of the state of the art, but also because its explicit aims and objectives offer a challenge to migration scholars worldwide to develop this new global paradigm further.

I. Lydia Potts, The World Labour Market: A History of Migration (London, 1990).

2. Leslie Page Moch, Moving Europeans: Migration in Western Europe since I650 (2nd edn., Bloomington, IN, 2003). 


\section{EUROCENTRISM}

What then might this development entail? First of all, notwithstanding Hoerder's explicit goal of moving away from a Eurocentric/Atlantocentric interpretation of migration history, after finishing the book it struck me that this is apparently not very easy. Although all parts of the world are covered in his book, Europe still plays a central role. A rough count reveals that almost half of the book is on migration within/from/to Europe ( 48 per cent), followed by Asia (I 9 per cent), Latin America (I 3 per cent), Africa (I 2 per cent) and - curiously - North America (with a meager 8 per cent). Moreover, looking more closely, it appears that most of the pages devoted to the non-Western world deal with migration streams that were induced by European expansion, mostly in the form of slaves (Africa), indentured labour (Asia), or the effects of colonialism in the twentieth century.

In this sense, Cultures in Contact is - strange as it may seem - very much a Eurocentric book, and my main question therefore is whether given the impact of European expansion since I 500 - this is unavoidable, or whether it might not be the result of a historical straightjacket, which makes Eurocentrism a much more tenacious enemy than we realize. Or, in other words, does the - in itself fully justified - attention paid to the negative effects of European conquest, domination, imperialism, and racism ultimately keep us enslaved in the very paradigm that we would like so much to destroy? And, taking this argument one step further, what alternative ways might there be to free ourselves from such a Eurocentric prison?

\section{RACISM AS A WESTERN PREROGATIVE}

Before exploring one of these avenues, let us first try to understand why migration scholars, myself included, are so interested in migration from the "Third World" to the Euro-Atlantic core. First of all, it seems to me, because it concerns an awful lot of people, and secondly because the categorization and treatment of these newcomers has produced deep and fundamental rifts within Western societies, with the position of the African Americans as the most obvious example. In a book that sets out to study "cultures in contact", these kinds of contact are, of course, highly interesting. In this sense, the choices made by Hoerder are understandable. However, focusing so much on hierarchical relationships between the Western world and the Rest also has its shady side. It seems unwillingly to imply that phenomena such as racism and colonialism are Western inventions, leaving similar mechanisms in other parts of the world largely untouched.

Although Hoerder does not start from such assumptions, and he devotes space to forced migrations and inequalities in cultural contacts 
without European interference, these analyses and descriptions are much less elaborate than those in the pages devoted to cases for which Europeans can be held responsible. Moreover, these "internal" slave systems (for example under Aztec and Inca rule, ${ }^{3}$ indigenous slavery traditions in Africa, unfree labor in Asia, and the Japanese treatment of immigrants) are described in more neutral terms than when Europeans are involved. Terms like racism and genocide seem to be reserved for "Whites", except for the genocide of the Armenians by the Turks, ${ }^{4}$ which Hoerder implicitly explains in terms of the replacement of the multicultural Ottoman doctrine by the nation-state ideology. Although he has a strong point in the case of the Turks, and the heirs of the Ottoman Empire in general, these examples in themselves do not mean that racism (or any other form of fundamental exclusion) was an exclusively Western phenomenon. Hoerder subscribes to this point of view, but close reading seems to suggest that the West is more to blame than the Rest. In one of the few instances that non-Europeans are accused of a doctrine of "genetic superiority" and "imperialist expansion", as in the case of Japan in the modern era, we are informed that the source of these ideas were "German and Harvard trained advisors".'

Although Hoerder is probably right that the semantics of the Japanese imperialist ideology have European roots, I doubt whether this was also the case for the ethnocentric/racist structure that characterized the Japanese treatment of other people. The racist treatment of the indigenous minority of the Burakumin, which started long before any Western influence on Japan, proves this point. Future research and studies will have to focus much more, therefore, on those forms of exclusion and exploitation - whether ethnocentric, racist, or religiously motivated - in other parts of the world, before massive Western influence made itself felt. By systematically comparing various societies, we should be able to understand the roots of exclusion, oppression, and injustice (in the spirit of Barrington Moore's Injustice, and, even earlier, the global comparisons in Shibutani and Kwan's Ethnic Stratification ${ }^{6}$ ), and account for their changing expression. Japan's Burakumin (or Eta), India's Untouchables and the caste system in general, and constructions of superiority among Incas, to mention a few obvious examples, "deserve" a more equal place in this global spectrum.

3. Hoerder, Cultures in Contact, pp. 187-189.

4. Ibid., p. 448.

5. Ibid., p. 375 .

6. Barrington Moore, Jr, Injustice: The Social Bases of Obedience and Revolt (London, 1978); Tamotsu Shibutani and Kian M. Kwan, Ethnic Stratification: A Comparative Approach (New York, 1965). 


\section{THE WEST AND THE REST}

This brings me to my second point, which focuses, not so much on the social history of Otherness, but on the global economic and institutional history and its impact on migration, both free and unfree. In Cultures in Contact, Hoerder does not neglect migrations and their relationship to the economic history of various parts of the world. He shows, for example, that in Africa, China, and India, before the intrusion of the West, migration was a structural aspect of these societies (as it was in Europe) and that each societal type produced its own elaborate migration systems in which unfree labor played an important role. Compared with those for Europe, however, these descriptions are very short and seem to serve mainly as the starting point for the European-led forced migrations from the sixteenth century onwards. A good example is China before I 800 , whose numerous and massive migration movements are dealt with in just five pages. ${ }^{7}$ Only when the Chinese leave their homeland and move either to other Asian destinations or (preferably) to Europe and the Americas does the number of words devoted to their vicissitudes increase dramatically.

From the vantage point of cultures in contact this uneven focus might be understandable and legitimate, but migration history in general suffers severely. For example, the fact that in the seventeenth and eighteenth centuries migrations within China were vast, and far outnumbered those in contemporary Europe, is overlooked. And, even more fundamentally, seeing the non-Western world mainly through the lens of European expansion and colonialism hinders a more systematic comparison of migration systems in various parts of the world.

If we want to move global migration history beyond the point to which Hoerder has now brought us, I believe that another perspective is needed. The most promising seems to be the debate on the rise of the West, which, in the past few years, has led to fierce discussions and fundamental new research on the economic development of China and India, with contributions from leading scholars such as André Gunder Frank, Jack Goody, Bin Wong, Kenneth Pomeranz, and James Blaut. Historians from the "California school" in particular, including Pomeranz and Wong, have recently challenged the idea expressed by David Landes and others that the economic success of the West was inevitable and can be explained by cultural, institutional, and technological characteristics embedded in Western culture. ${ }^{8}$ While the participants in this debate might differ on many things, their ongoing discussion has made clear that China and India,

7. Hoerder, Cultures in Contact, pp. I68-173.

8. Kenneth Pomeranz, The Great Divergence: China, Europe and the Making of the Modern World Economy (Princeton, NJ, 2000). 
as well as other regions in Asia, did not lag behind Europe, at least not very far, until the eighteenth century. Others, like Goody, ${ }^{9}$ have stressed the basic similarities between Asia, Africa, and Europe in terms of cultural, social, and economic patterns, such as the functioning of the family, the production of consumption goods, and the functioning of markets.

For the next step towards a global migration history, more balanced and equal comparisons of migration systems in various part of the world are therefore of the utmost importance. Abandoning The Colonizer's Model of the World, to quote the title of James Blaut's provocative study, will also increase our insight into migration systems in the West. ${ }^{10}$ A good example is Pomeranz's study, which compares economic developments in Europe and China. In his book he illustrates not only the massive character of the settlement policies of the Chinese state, involving more than Io million people during the late seventeenth and eighteenth centuries. ${ }^{\text {I }}$ More importantly, he explains the structural differences and similarities between migration systems in Europe and China, and links them to the economic and institutional histories of these parts of the world. He argues that in China migration was dominated much more by a "labor to land model" (settlement, colonization) and much less by "labor to capital", as in Europe. The absence of large-scale labor migration in China is explained by the institutional fact that this type of uncontrolled mobility was considered a threat by the Chinese state.

So while there was "no real European counterpart to the Chinese state's repeated efforts to facilitate mass migrations to areas where labor was scarce", ${ }^{12}$ Europe was special because it facilitated much more labor migration to capital-intensive regions, such as the Dutch Republic and Venice in the seventeenth century. ${ }^{\mathrm{I}}$ Finally, Pomeranz's comparison reveals that, notwithstanding the restrictions on labor migration in China, in general, labor to land migration was undertaken by free citizens, whom the state could tax and draft much more efficiently and easily than unfree or bound serfs. One of the things that we need in the future are these kinds of structural comparison of migratory regimes, which will both increase our knowledge of global social and economic history in general, and of migration in particular. ${ }^{14}$ The migration of slaves and indentured labour

9. Jack Goody, The East in the West (Cambridge, I996).

I0. James Blaut, The Colonizer's Model of the World: Geographical Diffusionism and Eurocentric History (New York, 1993).

I I. Pomeranz, The Great Divergence, p. 84.

I 2. Ibid., p. 83 .

I3. Jan Lucassen, "No Golden Age without Migration? The Case of the Dutch Republic in a Comparative Perspective", in S. Cavaciocchi (ed.), Le Migrazioni in Europa Secc. XIII-XVIII (Prato, 1994), pp. $775-797$.

I4. A very recent excellent attempt giving a more balanced overview of Asian migrations and rejecting the idea, also present in Hoerder's work, that the causes of migration among Asians 
from the non-West to the world dominated by the West should of course be included, but within the more general framework of indigenous systems and regimes.

A second study that might be a source of inspiration is the book by the British anthropologist, Jack Goody, The East in the West, which we have already mentioned. Although he barely deals with migration at all, his global comparative approach offers many insights. Looking for structural similarities between the West and the East, and focusing to a large extent on India, he argues that both Marx's ideas on the "Asiatic mode of production" and those of Max Weber on the spiritual and mental uniqueness of the West are misleading. In the realms of production, consumption, and markets, as well as the functioning of the family, Goody suggests there was convergence. In view of the importance of the family for migration strategies and decisions, a point fully endorsed by Hoerder, it would be interesting to explore this avenue much more systematically. In the spirit of Shibutani and Kwan, Pomeranz, and Goody, Hoerder's landmark study offers an important starting point for such new research angles, and I am grateful that he has inspired me to consider new perspectives on global migration history for the future.

were different because of colonial penetration by Europeans is Adam McKeown, "Global Migration I846-I940", Journal of World History, is (2004), pp. I55-I89, and especially pp. I70-I7I. 


\title{
Response to Critics
}

\author{
DIRK HOERDER
}

I am grateful for the thoughtful comments of my critics, and their global scope, and will address some of the many important themes raised. In writing global history, where do we start? Any starting point implies a perspective. My choice to start from the tri-continental, tri-religious, and many-cultured Mediterranean world permitted an early critical view of geographic-continental history approaches: European, African, or Asian. When we talk about continents or peoples living in one particular continent, our languages, with their implied connotations of distinct continent-wide cultural and colour-of-skin specifics, mislead us into simplifications and confine us to particular paths of thought. The Mediterranean-centred departure point also permitted a discussion of the mingling of cultures as well as of early conflicts from the start. Muslims lived in considerable numbers in southern Europe's regions, Christians in North African cities, and Jews in many places. Africans with animistic beliefs were part of this world.

Yet, for all its advantages, the starting region also precluded the possibility of assuming perspectives from a different section of the globe. When beginning to write the book, I attempted to counterpoise the Mediterranean by a China-centred perspective. It turned out that this was far more difficult than I had imagined. The four cardinal points of the compass applied differently: the Americas would have been in the east, India and Arabia in the west. For each and every sentence I was writing then, I had to restructure my own mental map. While this is an important exercise to escape one's preconceived, but usually not articulated, perspective, it made not only for difficult writing, but would also have made for extremely difficult reading. If reading is difficult for scholars, how would students come to terms with multiple geographic perspectives? I thus chose to attempt to represent all regions of the world in the maps and achieve equal treatment there.

Equal treatment was also what I had intended to achieve for patterns of migration in all regions and cultures of the globe. However, some are not only privileged by wealth but also by the amount of scholarship available. The literature I could draw on privileged North America, Europe, and the Atlantic world as a whole. This was both a function of languages I can read and of concepts hidden behind words. My languages are limited to three 
European ones, German, English, and French; student assistants added Spanish, Portuguese, Polish, and Russian. None of the Asian or African languages were accessible to me except through translators. As to meanings behind words: the societies of the Americas, Australia, and New Zealand, perhaps South Africa, have been labelled immigration countries, European societies emigration countries. The two North American societies are more in the centre of debates about immigration than South and Central American societies; and African and Asian societies are on the margins of such debates (in the Atlantic world's scholarship) or are not "in view" at all. Thus, far more literature was available to me on the Atlantic world than on the Pacific one, or on the worlds of the Indian Ocean. If I read the English, French, and Spanishlanguage studies by authors with Asian and African languages correctly, then I did not miss scholarship on migration in local and regional languages. Wealth and power results in hegemony over research discourses, and privileges some perspectives over others.

Power relationships insert themselves also into analysis and narration as regards the organization of the study. For long, the Americas and their cultures remained not only distinct but also separate from the tricontinental Mediterranean and later from western Europe; the trading circuits of the Indian Ocean were connected through the mediation of Muslim merchants; the Chinese diaspora remained bounded in the southeast Asian worlds. European colonialism, and later the Atlantic world's imperialism, provided connecting structures. The weight - dead weight? - of historic developments imposes itself on our modern mental maps and cultural conceptualizations. However, rather than taking one starting point, the late medieval Mediterranean world, the study could have started with many distinct developments by cultural region/continent and might then have moved to interactions and on to global connectedness from the fifteenth century on.

Conceptually, a start from many unconnected societies with no connecting lines might be called both a postmodern technique as well as a traditional one, adequately reflecting parallel, if differing historical developments. Since research on migration and cultural exchange is progressing rapidly, it might be worthwhile to attempt to assemble a team of scholars who specialize in different regions of the globe, start a migration history from the many regions, and then weave the strands together. Will this be a weaving of strands or one grand synthesis with a single underlying theory? It will certainly have to take into account other approaches to world history, whether theories of world systems or of comparisons between Asia, Africa, Arabia, and Europe.

I have tried to avoid the many customary designations that muddle concepts but that seem so obvious in everyday speech. Geographic continents, political states, constructed cultural units like nations, or lived 
cultural units of one particular cultural group - all mix perspectives. "The Chinese" migrants came from many regions, "the Chinese empire" changed in political scope and geographic spaces. So did all European polities. I prefer "meso-level" units that have validity at a particular conjuncture in historic time, the Mediterranean world, the southern provinces of China, the central Siberian section of the Romanov empire, or the west African coastal cultures. The term meso-level, as all terms, has its own trickiness: viewed from a local place, the surrounding region is the meso-level, the state or some larger geographic entity the macro-level. Viewed from continents or in a global perspective, meso-level analysis may encompass macro-regions not necessarily confined to the same land-mass. Just as the Inuit have dozens of words for snow to describe its multiple variants adequately, I would have liked our language(s) to provide me with dozens of alternatives for meso-level units, whether geographic, economic, societal, or political.

Until now, I have been dealing with spaces, the pitfalls of language, and perspectives. In the history of migration and cultural exchange it is human movement and interaction, rather than the space, that takes primacy in analysis. Contact between cultures may take conflictual, cooperative, or consensual forms. Have I privileged the positive over the destructive? Have I placed too little emphasis on victimization? To study migration and interaction implies a choice. Had I selected war and nationhood, conflict and destruction would have played a far larger role. But in processes of migration and cultural interaction, destructive phases are evident, too: Both the Spanish and Dutch colonizer migrants in southeast Asia destroyed, even massacred, vibrant communities of migrant Chinese that supplied trade good to them as well as services. The migration of Europeans to the Americas implied the near-genocide - not necessarily intentional - of the indigenous cultures. In the Caribbean, the Arawak preferred to kill their babies and themselves to escape Spanish exploitation.

Still, I would distinguish between the sufferings or the annihilation of individuals and whole groups, for example of the Chinese in Batavia, and cultural impact: Dutch East India had a Chinese component before and after the massacre. Opportunities in Batavia induced new migrants to come, even in full knowledge of the atrocious violence that had just happened. Human strategies take into account dangers but sometimes minimize them. What I tried to make clear, but what may need even more emphasis, is that cultural exchange takes place in power relationships and sociocultural hierarchies. This is why people in a weaker position and considered more visible than others, Chinese in Indonesia or AfroAmericans in the US, are targeted more easily in intercultural violence than structures or corrupt officials.

As to outcomes of contact, whether segregation, marginalization, or métissage, the example of the Beothuk, who withdrew from contact, lost 
their food supplies, and succumbed, points to an issue that is implied in the term "immigration society" and that has been in the back of my mind, without always being clearly articulated. I would posit that societies open to incorporate newcomers develop in more dynamic ways than societies that marginalize cultural and material input of other cultures. This goes beyond the cliche that the North American "immigration" societies were more innovative and dynamic than the European ones. Immigrants in European cities were often constructed as "alien", and as threatening artisanal corporative structures which protected the living standards of resident families. Protection of the standard of living, however, was often compromised by protection of "traditional" ways of production or distribution. Living by rules or evaluating options seems to be an important distinction. Some societies or cultural groups in societies develop the social competence to deal with diversity and incorporate what seems beneficial (to some, at least); others lack competence to develop strategies for change. Worship of the past, whether of burial places of specific ancestors, or of sites of battles, or of national/dynastic grandeur, seems to militate against development and cultural interaction.

To change the perspective from stateside actors to common people does imply a reallocation of responsibility. As long as common people are considered as victims, they do not share responsibility. However, slavery was common in Africa before Europeans arrived, and warrior states supplied European and American traders with enslaved men, women, and children. Similarly, if Asian cultures were not inferior, as has been assumed in the Atlantic world's discourse for long, the racism and the hierarchization of lightness of colour of skin in Asian societies is a genuine responsibility of intellectual gatekeepers, and perhaps common people, in these societies. However, in my reading of historic developments, European expansion, and later US expansion (and to a lesser degree the expansion of the Soviet Union) gave more agency across the globe to the powers involved, and thus places additional responsibility - and that may mean blame - on these societies, their elites, but through the trickle-down effect of imperialism and global apartheid also on societies as a whole.

Have I underemphasized racism and oppression generic to other societies? In my interpretation, the combination of mercantile (later industrial) with state power - which was the opposite from developments in China, Japan, or Africa - permitted a position of strength and armed imposition not matched in the outreach of other societies. Furthermore, given the long history of Euro-American self-allocation of superiority, it seems advisable to permit criticism of racism elsewhere come from such racist cultures themselves, rather than from a Europe, once again proactive. Agency, its ethics, and responsibility are linked.

In conclusion, migration and cultural exchange demand a comprehensive narrative after a century of divisive nation-state historiography. But 
just as migrations need explanation, phenomena and patterns of migration explain other socioeconomic and political development. Common migrants as well as some elite members created the Chinese diaspora, dug the Panama canal, worked on the plantations, and care for children and the elderly in the households of today's wealthy segments of the world. 